\title{
HOW THE ELITE CAPTURE CRITIQUE IS USED TO LEGITIMISE TOP-DOWN CONTROL OF DEVELOPMENT RESOURCES
}

\author{
Peter Shapland, Annemarie van Paassen, \\ and Conny Almekinders
}

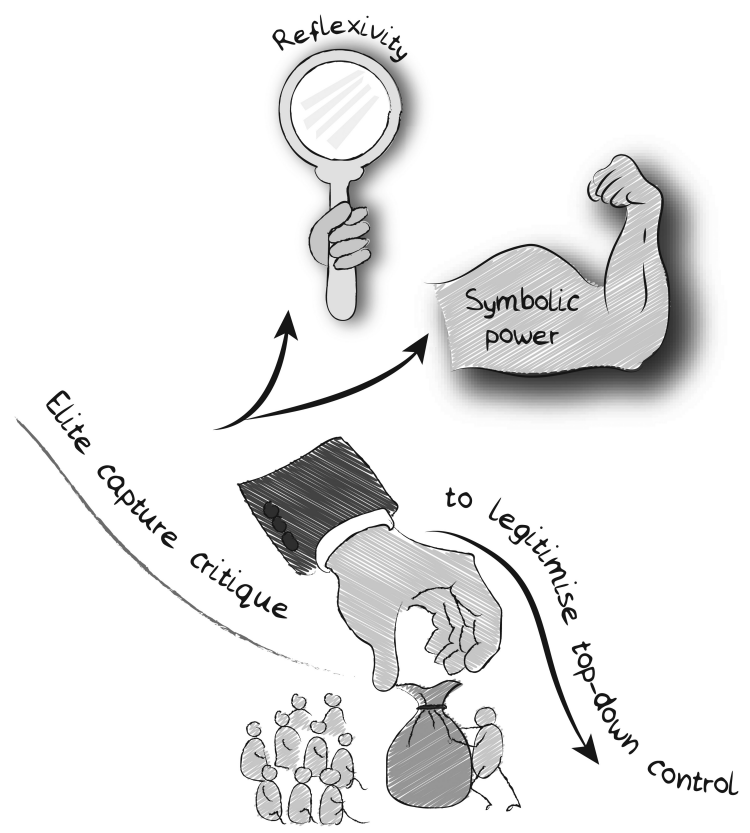

\section{Introduction}

Community-Driven Development (CDD) and other bottom-up approaches empower poor communities with control over project resources (Dongier et al., 2003), but they are criticised for their vulnerability to elite capture (JeanPhilippe Platteau, 2004). Elite capture largely refers to the phenomena of local 
elites leveraging superior political and economic status to usurp the benefits of community development and decentralisation programmes that transfer control over public goods to lower-level governance structures (Bardhan \& Mookherjee, 2006; Dasgupta \& Beard, 2007; Kusumawati \& Visser, 2016; J-P. Platteau \& Abraham, 2002). Lower-level governance structures are widely assumed to be more susceptible to elite capture because of greater opportunities for collusion (Bardhan \& Mookherjee, 2005; Dutta, 2009).

Some critical authors note, however, that development interventions can be understood in terms of political and normative struggles that determine resource flows and socially constructed notions of development (Long, 2003, p. 41). The elite capture debate is a site of one of these struggles - development institutions are reluctant to relinquish control over the conditions in which development projects are implemented (Bornstein et al., 2006, pp. 4-8; Chambers, 2010), and development researchers explicitly employ the elite capture critique to legitimise top-down control over development resources (Classen et al., 2008; D’Exelle, 2009; Fox, 2020; Kusumawati \& Visser, 2016; Lawson, 2011; Mansuri \& Rao, 2003; Jean-Philippe Platteau, 2004; J-P. Platteau \& Abraham, 2002; Ward et al., 2018; Sam Wong, 2010).

According to Bourdieu, our worldviews emerge from historical struggles over symbolic and material power and lead us to experience arbitrary social power relations as justified and even necessary (Pierrre Bourdieu, 1977, pp. 80-82). Symbolic power imposes classification systems that legitimise structures of domination (Bourdieu \& Wacquant, 1992; p. 13), and it thereby operates on our pre-reflective 'commonsense' understanding of the world: 'below the level of calculation and even consciousness' one falls into acceptance of arbitrary power relations without taking into account the coincidence between our dispositions and position (Pierre Bourdieu \& Wacquant, 1992, p. 128). Bourdieu's thinking appears relevant because our disposition toward the elite capture critique frequently aligns with our position in the power struggle. Development researchers and practitioners identify elite capture as the central problem in bottomup development approaches (Casey, 2018; Duchoslav, 2013; Fox, 2020), while the participants of development projects see many of these alleged instances of elite capture as unproblematic or even pro-social behaviour (Beath et al., 2011; Conning \& Kevane, 2002; Khatun et al., 2015; Kita, 2019; Mawomo, 2019, p. 340; Jean-Philippe Platteau, 2004, 2009; Rao \& Ibáñez, 2005).

In this chapter, we investigate the pertinence and use of the notion of elite capture. This is a fraught exercise because we are vulnerable to reaffirming symbols and entrenched power relations when we consider issues of empowerment and capture, as we tend to see them within frameworks that legitimise the existing relations of domination. For example, when development institutions capture development resources and decision-making powers, it's generally considered a necessity of good project management, but when local elites capture them, it's often considered to be 'pernicious' graft that aggravates oppressive social hierarchies (Andersson et al., 2018; Jean-Philippe Platteau, 2004). On the 
other side of the elite capture debate, the project participants' acceptance of elite capture could also emerge from the internalisation of symbolic power that legitimises arbitrary power relations within the villages. Bourdieu's reflexive approach challenges us to be aware of how symbolic power has shaped the pre-reflective framework of our thinking.

To appreciate the pertinence of the elite capture critique, we investigate the origin and form of the concept and debate in development practice and science, being cognisant of the historical struggle over material and symbolic power as elaborated by Bourdieu. Besides this general historical analysis of the elite capture critique, we also highlight issues forwarded in the literature that show flaws of the mainstream conceptualisation, which needs to be considered for a more nuanced and context-specific analysis. Our contribution to the debate is to show how the problematisation of elite capture in the mainstream development discourse is a form of symbolic power that legitimises arbitrary power relations between international development institutions and rural communities in the Global South.

\section{How elite capture is understood and used \\ The emergence of the concept of elite capture}

Throughout its evolution, the elite capture critique has functioned as a form of symbolic power that legitimises centralised forms of governance over rural areas. Bardhan and Mookherjee (2000) peg the origins of the elite capture critique to Federalist Paper No.10 - the USA's founding fathers wrote the Federalist Papers to lobby for the adoption of a national constitution (Miller, 1988). The notion of elite capture later emerged in the Global South when the colonialists used it to justify their policies of extracting wealth from agricultural producers in the Global South (Li, 2007, p. 35; Spurr, 1993, p. 77). The centralised authority's struggle against local elites appeared again in the post-colonial states. Boone's (1998) comparative analysis of local institutions in Senegal, Cote d'Ivoire, and Ghana shows how post-colonial institutions were shaped by the national government's struggle with rural elites to capture the agricultural surplus generated by small farmers, in order to nurture the development of urban/industrial sectors of the economy. Boone (2003) and le Meur (1999) argue that for nascent central governments the underlying goal of 'rural development' was to extract agricultural surplus. The decentralisation debate (from 1985 to the present day) is also characterised by this same struggle over rural surplus between the government and local elites (Boone, 2003).

The concern about elite capture appeared in international development when Holdcroft (1978) wrote about its emergence in community development in the 1950s. The elite capture critique rose to prominence in development studies as a response to the decentralisation debate and bottom-up development approaches; see Figures 5.1 and 5.2. Argawal (2001), Guijt and Shah (1998), and Kothari (2001) laid the groundwork by criticising proponents of community 


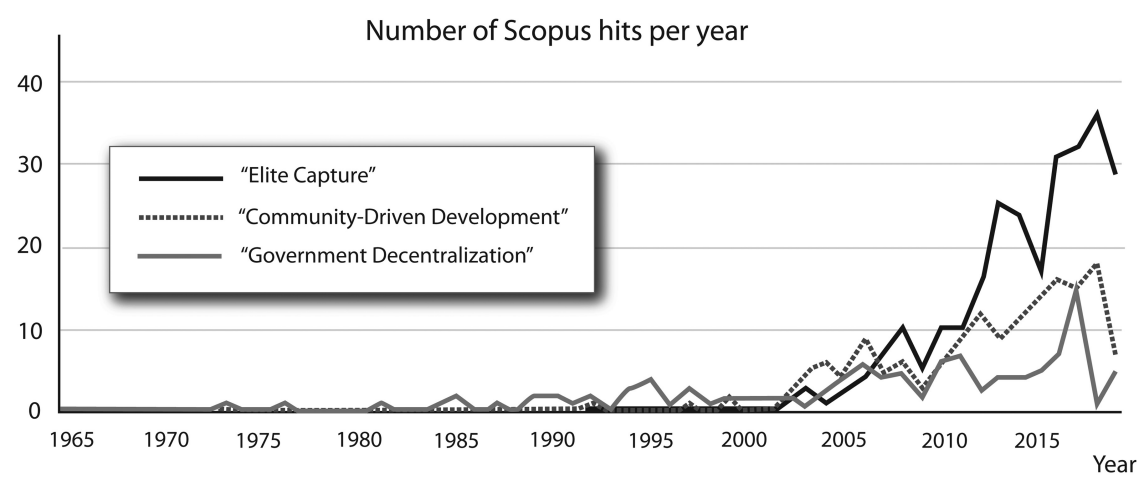

FIGURE 5.1 Scopus searches show how the term 'elite capture' rises in usage compared to 'Community-Driven Development' and 'Decentralisation,' eventually overtaking both of them

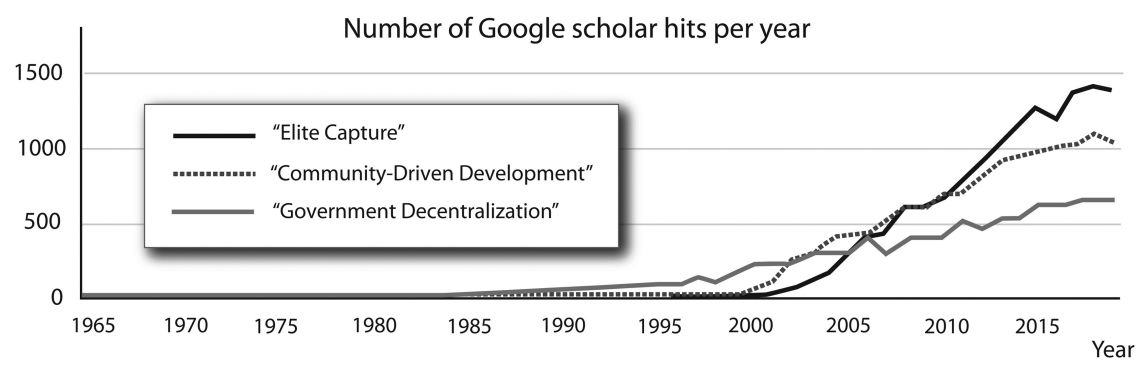

FIGURE 5.2 Google Scholar search results. Differences correspond to Google Scholar's wider (at times more eclectic) coverage than both Web of Science and Scopus. By including grey literature and technical documents, Google Scholar can be more representative of debates which involve both scientific and policy communities

empowerment for their tendency to uncritically celebrate the 'local community' without considering entrenched local power relations. Platteau 'set the tone' of the elite capture critique (Kusumawati \& Visser, 2016, p. 304) when he argued that 'personalised relationships in tribal societies' lead to community imperfections, inequality, and elite capture (Jean-Philippe Platteau, 2004; J-P. Platteau \& Abraham, 2002, p. 111). Numerous scholars since (D’Exelle, 2009; Iversen et al., 2006; Labonte, 2012; Ribot, 2004; Williams et al., 2003; Sam Wong, 2010) have underscored the elite capture critique. However, other research on CDD and decentralisation shows how the act of devolving power to communities can undermine elite capture (Blair, 2000; Dufhues et al., 2015; Fritzen, 2007), but it takes marginalised groups longer to mobilise and gain control over resources devolved to communities (J. F. Lund \& Saito-Jensen, 2013; Manor, 
1999, p. 48). Some scholars make the distinction between elite capture (elite's usurping undue portions of project benefits for personal gain) and elite control (elite's controlling decision-making processes potentially for everyone's benefit) (Dasgupta \& Beard, 2007; Fritzen, 2007; Lucas, 2016; Musgrave \& Wong, 2016; Rao \& Ibáñez, 2005; Saguin, 2018). These studies demonstrate cases of elites controlling CDD resources in equitable and pro-poor manners. Finally, of the five existing meta-analyses of CDD programmes, four conclude that elite capture is generally not a problem (Casey, 2018; Everatt \& Gwagwa, 2005; Kumar et al., 2005; Susan Wong, 2012) and the fifth finds that elite capture in CDD is context specific (Mansuri \& Rao, 2003).

In the late 20 th century, development theory largely characterised local elites as impediments to economic development and social change (Mitra, 1991). The elite capture critique perpetuates this ethos by focusing on the negative aspects of local elites while disregarding their pro-social functions (Kusumawati \& Visser, 2016). Development professionals tell countless stories of elite capture while the research shows mixed results (Duchoslav, 2013).

A major challenge in development is the constant effort of powerful actors throughout the aid chain to capture resources that are intended for the world's poor (Wenar, 2006). Development's focus on upward accountability (Bornstein et al., 2006) has made accountability a powerful weapon that development actors strategically use to delegitimise their competitors in the struggle for resources (Thomas et al., 2008). The use of the elite capture critique emerged in mainstream development, despite more nuanced research studies and mixed results because it serves the interests of higher-level structures. Throughout its evolution-in American federalism, colonialism, post-colonial state formation, decentralisation, and now development-the elite capture critique has been inseparable from the economic and political power it serves.

\section{The narrow framing of elite capture in the development arena}

A literature review on the use of the term 'elite capture' reveals an interesting trend-the term is mostly used in reference to local elites in the Global South (see Figure 5.3). By explicitly employing the elite capture critique to legitimise top-down control over development resources, development researchers and practitioners implicitly argue that elite capture in decentralisation and CDD is worse than the capture that occurs when national elites or development institutions maintain top-down control over development resources. However, the evidence to support this claim does not exist.

Regarding national-level elites ('corruption'), Bardhan and Mookherjee (1999) developed a theoretical model to compare elite capture and national-level corruption, and found that capture is too context specific to support generalisable results. Bardhan and Mookherjee (2005, p. 40) subsequently conducted a literature review and concluded that the effects of decentralisation on elite capture and national corruption are too complex for summarisation yet 'tend to indicate 


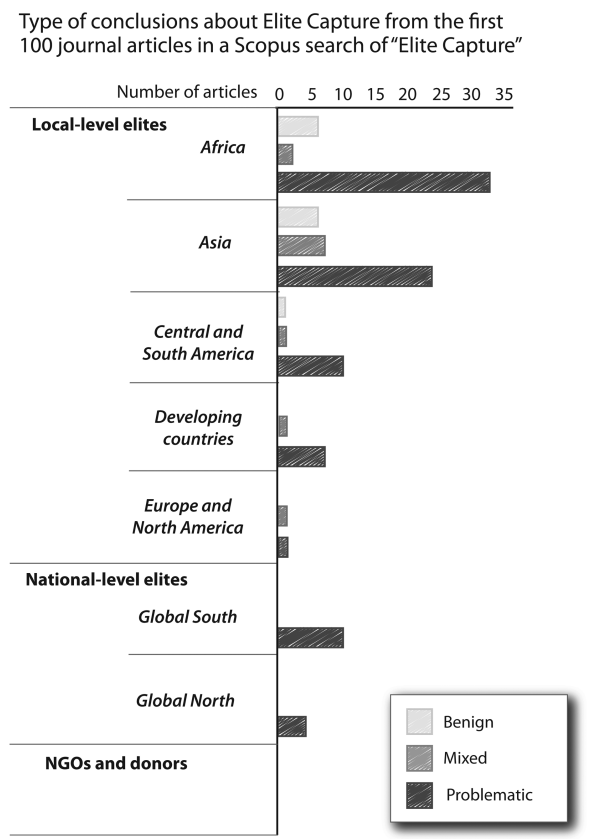

FIGURE 5.3 A Scopus search of 'elite capture' (no time period constraints) produces articles that are largely about lower-level governance structures in the Global South. ${ }^{1}$

that the problems of local capture within communities have not been excessive and have been dominated by beneficial effects on targeting across communities.'

Regarding NGO and donor capture (also known as 'lodging') (Harsh et al., 2010), the elite capture critique simply ignores the capture and control of resources at these higher levels. Looking at Figure 5.3, how can we conclude that local elites in the Global South are more likely to control and capture resources than NGOs and donors, when they are excluded from the elite capture debate? We found only two case studies that look into the matter. Both studies show that elite capture in devolved development projects is small compared to targeting errors and misallocation in top-down projects, and neither compared elite capture to NGO/donor capture (Alatas et al., 2019; Galasso \& Ravallion, 2005).

The narrow framing of elite capture in CDD evaluates it in a vacuum without taking into account higher levels of control and capture in the top-down organisation of development projects, in which the local communities are routinely excluded from control over development resources and disempowered (Khadka, 2009, p. 231; Pfeiffer, 2003; Power et al., 2002; Townsend et al., 2002). Bornstein et al. (2006, pp. 4-8) and Chambers (2010) point out that the prioritisation of upward accountability (and the concomitant use of logical frameworks, verifiable indicators, and results-based management) leads NGOs to strictly control 
the conditions in which projects are implemented and create a disempowering effect among the target populations. NGO projects tend to arrive at rural villages as a fixed package of activities and if-then clauses (within a Theory of Change) that claim to account for the communities' context, behaviours, and motivations. Large donors currently tend to require proposals to be organised according to an overarching Theory of Change that resource-intensive Monitoring and Evaluation (M\&E) processes validate via a predictive Results Framework. These practices conceive of the farmers as deterministic 'things' that will conform to the project's predictions, rendering the farmers passive in their own development (Chambers, 2010). This mode of practice is designed to reveal rapid and easily observed results (Boulding, 2009), while the less visible, empowerment-related goals of development initiatives, like self-determination, community initiative, and a self-reliant capacity to thrive, are neglected (Power et al., 2002).

The question isn't whether community-driven approaches face challenges with elite control and capture (they do). The question is whether elite capture in community-driven approaches is more or less disempowering than the current top-down model dominating international development, but the elite capture critique ignores capture by NGOs and donors.

The elite capture critique also fails to consider global inequality. Zooming out and taking a brief look at inequality and the elite at the global level, one finds a global Gini Coefficient ranging from 0.61 to 0.71 (Hillebrand, 2009; UNDP, 2010), with eight people controlling as much wealth as half of humanity (Hardoon, 2017). Stand up from your desk and seek out both the leader and a groundskeeper at your institution and inquire into their respective renumeration-claiming that elites capture more resources than non-elites is tautological. So why is the development community so preoccupied with elite capture in rural communities in the Global South, where the intra-village Gini Coefficient can be as low as 0.14 (Arcand \& Wagner, 2016)?

The elite capture critique effectively frames 'capture' on local elites in the Global South and leads us to ignore capture that occurs in NGOs/donors and also global inequality. This is how the symbolic power of the elite capture critique operates on our pre-reflective thinking-it frames the boundaries of a classification around a disempowered group. Thus, symbolic power imposes classification systems that legitimise structures of domination.

\section{Elite capture is context specific: $A$ review of rural West African elites and their responsibilities}

The proclivity and capacity of local elites to capture resources in CDD or government decentralisation is highly dependent on the context (Bardhan \& Mookherjee, 2000; Smoke, 2003). Our analysis is focused on local elite living in Labor-Constrained Agricultural Systems in West Africa (LCASWA) to demonstrate a context where the broad strokes of the elite capture critique appear less relevant. 
The financial means of the village elite in LCASWA are categorically different from Western notions of the elite. Dryland agricultural production in West Africa is characterised by high levels of uncertainty and low levels of possible capital accumulation (Long, 2003, p. 102). In Sahelian West Africa, agro-pastoralists have an unpredictable and short window of time to grow as much food as possible. Based on the last 70 years of climate data, the probability of a very good year is $12 \%$, a good year is $28 \%$, a normal year is $43 \%$, a mediocre year is $17 \%$, and a catastrophic year is $14 \%$ (Aune, 2011). The agro-pastoralists' proclivity for early-maturing varieties, despite their lower yield capacity in good rainfall years, is indicative of the prevailing agricultural strategy in a harsh and unpredictable environment: they are more interested in hedging against risk than maximising production.

To cope with the unpredictable environment, the majority of rural Africans inhabit cultures that apply social pressure on anyone with a surplus (especially the local elite) to share their wealth with poor friends and family (Alby \& Auriol, 2010; Bergh, 2004; Kazianga, 2006; Jean-Philippe Platteau, 2006). Bernard et al. (2008) frame this social pressure as a crucial safety net for the above-mentioned risks associated with dryland agricultural production in West Africa. Households that fall into financial crisis often sell livestock as a source of emergency cash, but for those who are too poor to own livestock, their true safety net is their participation in the extended family (Bulte et al., 2018, p. 67). As a result, economic differentiation is more focused on staving off poverty than accumulation (C. Lund \& Benjaminsen, 2001, p. 300). Wealth distribution in rural West Africa is characterised by relative equality (Saul, 1983). A measure of intra-community inequality in 177 villages in Senegal revealed Gini Coefficients at a mere 0.14 to 0.18 , 'indicating that at the village level the households are equally poor' (Arcand \& Wagner, 2016, p. 109).

Village elite in LCASWA are less able to entrench their position of wealth because the primary constraint in agriculture is labour, not land (Bulte et al., 2018, p. 61; Hussein \& Nelson, 1998). In land-constrained agricultural systems, village elites can entrench their position via the acquisition of land. Research from land-constrained systems has confirmed that unequal land holdings play an important role in the prevalence of elite capture (Bardhan \& Mookherjee, 2003; Galasso \& Ravallion, 2005; Pan \& Christiaensen, 2012). In labour-constrained systems, however, the competition over labour has a greater impact on productivity and wealth (Binswanger \& McIntire, 1987; Bulte et al., 2018, pp. 60-61; Saul, 1983). The quantity of labour a household can access is highly dynamic - households grow and contract, members shift in and out of working age, and other members emigrate to urban areas. Shifting quantities of labour, combined with low levels of possible capital accumulation in dryland agriculture, create unstable and ambiguous class structures (Berry, 1993, p. 184; Long, 2003, p. 102). Nevertheless, outsiders from the Global North have a history of projecting rigidity onto fluid class structures in traditional Sub-Saharan systems (Berry, 1993, p. 25). The under-appreciation of rural class fluidity is not endemic 
to LACSWA - it has been widely observed in rural India too, despite the caste system (Powis, 2007).

The elite capture critique characterises the rural non-elite in the Global South as powerless vis-à-vis the local elite (Labonte, 2012; Jean-Philippe Platteau, 2004; Williams et al., 2003; Sam Wong, 2013). However, some scholars show the various accountability mechanisms that non-elites uphold to ensure just leadership (Arnall et al., 2013; Scott, 1985), and still others argue that local elites have little room for manoeuvre in the struggle for influence and depend on the non-elites for support (C. Lund \& Benjaminsen, 2001, p. 95; J. F. Lund \& SaitoJensen, 2013; Musgrave \& Wong, 2016). In this same vein, Pitcher et al. (2009) point out that the stability of 'personalised leadership' depends on reciprocity and mutual respect. Thus, where Platteau (2002) sees an immediate cause of elite capture, Pitcher et al. see a functioning accountability mechanism grounded in personal interaction. 'Scholarly debates over participatory development rarely explicitly address [this] core dimension of accountability: countervailing power' (Fox, 2020, p. 2). Including countervailing power dynamics in participatory development studies would provide a more nuanced picture.

\section{Elite capture in perspective: Including higher- level capture in the elite capture critique}

The elite capture critique is not capable of processing the various ways that resources and decision-making powers in a multimillion-dollar grant are captured by numerous kinds of elites before it reaches the intended project participants.

While a thorough comparison of the disempowering effects of top-down development and elite capture is beyond the scope of this article, a brief review of resource capture by local elites and NGOs is possible. Unfortunately, detailed information of NGO capture in a typical top-down project is unavailable because NGOs routinely recategorise administrative costs as programmatic costs to hide their overheads (Walsh \& Lenihan, 2006). Conversations with NGO staff reveal that staff salaries, administrative costs, equipment for the NGOs (computers, cars, etc.), and air travel typically comprise at least $50 \%$ of project budgets, and some studies show that NGO and donor capture can be as high as 60-90\% (Acemoglu \& Robinson, 2012, p. 452; Harsh et al., 2010), but a more concrete benchmark is necessary for our purposes. NGOs implementing CDD projects provide a straightforward means of measuring NGO capture: the NGO's total project budget minus the amount issued to the communities as block grants (NGO budget-block grants $=$ NGO capture) ${ }^{2}$

The elite capture critique has enabled/justified NGOs to implement intensive community trainings to ensure broad participation in resource allocation (Casey, 2018; Fritzen, 2007; Lawson, 2011). This heavy-handed approach to CDD, coupled with resource-intensive $M \& E$ practices and other NGO lodging leads to high levels of capture. Casey's (2011) evaluation of the GoBifo, a CDD project in Liberia, showed that the implementing NGO spent $30 \%$ of the budget on social 
facilitation (to prevent elite capture), $23 \%$ on NGO operating costs, and $47 \%$ was devolved to the communities in the form of grants. Casey et al. (2012) showed that local elites captured minimal levels of the grants. Thus, the non-elites of the GoBifo communities gained access to almost half of the grant. Tuungane 1, another large-sale CDD program with heavy NGO involvement, allocated $43 \%$ of the $\mathcal{E}^{3} 30$ million budget to the communities in the form of block grants and $57 \%$ went to the implementing NGO's operating/facilitation costs. The project discovered only $£ 21,251$ of locally-misappropriated funds throughout the $\mathcal{N}^{13}$ million in block grants - a fraction of $1 \%$ was captured by the local elite in this heavy-handed approach to CDD (IRC \& CARE, 2012). Humphreys (2012) conducted a follow-up study to the Tuungane project. Using a random sampling of Tuungane and control villages, Humphrey's research team issued $\$ 1,000$ to each community for a development project of their choosing. In the follow-up study, the research team did not conduct community meetings to promote inclusivity and transparency. They found that an average of $15 \%$ of the grant (in both Tuungane 1 and control villages) was not accounted for, thus insinuating the level of elite capture. Thus, NGO implementing Tuungane captured 57\%, while the local elites captured $15 \%$.

\section{Discussion}

\section{Researchers' normativities and worldviews projected into the elite capture critique}

According to Bourdieu, 'scientists exercise symbolic power by shaping the categories through which agents perceive the social world; indeed, the potential symbolic effects of scientific theories are all the greater because science claims to speak in the name of the universal (i.e. of reason) and to be neutral and impartial with respect to social struggles' (Cronin, 1996, p. 76). However, social scientists are prone to projecting their own worldview onto the social practices that they research (Pierre Bourdieu, 1980, pp. 29-41, 1989, p. 42). For example, Platteau (2004, p. 27) explains the project participants' lack of concern for elite capture by arguing that they lack the reflective capacity to see beyond 'the logic of clientelistic politics characteristic of the African continent.' However, perhaps it is development researchers who struggle to see beyond their worldview when analysing foreign groups. After all, it appears that researchers and the people living in LCASWA villages each arrive at distinct conclusions about elite capture, which align with their own experiences of social stratification and the concomitant pro- or anti-social conceptions of the elite.

While much of the elite capture research uses qualitative surveys that consider the community members' perspectives, a lot of the elite capture research still relies on quantitative proxies for capture that are devised by the researchers. These proxies typically calculate elite capture by adding up the resources that benefit the local elite versus those directly benefiting the poor, or by attempting 
to account for all the community's project expenditures and subtracting that from the amount of the community grant (on the assumption the elite captured the missing portion). These simple accounting exercises fail to account for the interlocking complexities of local tradition, legitimacy, and pro-social service delivery by the local leadership (Takasaki, 2011b), nor do they account for cultural norms and traditions of allocation and mutual care that could be disrupted by perfectly equal allocations (Kita, 2019). The simple accounting measures are also prone to reifying researchers' unacknowledged normative assumptions that are not necessarily shared by the people they study. For example, although some research measures elite capture via the selection of public goods that favour elites (Nath, 2014), other studies measure it by the proportion of community expenditure on private goods targeting the poorest people versus public good projects (Araujo et al., 2008; Darmawan, 2014; Darmawan \& Klasen, 2013). This method subjects the target communities to the researchers' normative judgment that only the community's poorest people should benefit from development. When community leaders decide that their community would be better served by a public goods project that targets everyone, their actions were classified as elite capture. Kusumawati and Visser (2016, p. 305) argue that elite capture 'studies remain too much driven by a northern, hegemonic view and expatriate concern with the institutional norm of a Weberian transparent, democratic, and inclusive, but narrowly defined financial accountability.'

\section{The elite capture critique requires a reflexive approach}

Bourdieu's reflexive approach enabled us to look at the history and emergence of the elite capture critique, serving the interests of central authorities in American federalism, colonialism, post-colonial state formation, decentralisation, just as it now serves top-down development institutions in the struggle over development resources. In mainstream development, the elite capture critique is explicitly used (as a form of symbolic power) to legitimise top-down approaches and conceal the arbitrary relations of dominance between development institutions and local communities. This symbolic power operates on our pre-reflective understanding of top-down development by framing capture exclusively around the local elites, and researchers seem prone to easily align their research, rather than critically question this perspective. Consequently, the elite capture critique is apt to misunderstand the functions, roles, and capacities of local elite, as our LCASWA case study showed.

\section{Notes}

1 The category of Local Level refers to capture by village/community elites or local/ regional government actors, and the category of National Level refers to capture by national government actors and the elites in their orbit. The Developing Countries column is not a product of our classification. The authors of these articles wrote about the placeless local elite of 'developing countries'-Escobar (1995, p. 53) argued that a 
major effect of the development discourse is the erasure of the complexity and diversity of developing country populations. The Global South column includes research about 'Eastern and Southern Africa', Ghana, Cambodia, Indonesia, Bangladesh, and North Korea. Of the four articles that fell into the category of National-Level elite capture in the Global North, two were about elite capture in all countries (Morck et al., 2011; Oberlack et al., 2016), one was about 19th century Russia (Finkel, 2015), and the final one was about energy politics in New Zealand (MacArthur and Matthewman, 2018). The one article about local elite capture in Western Europe was about Swedish democracy in the early 1900s (Hinnerich and Pettersson-Lidbom, 2014). Only two articles were discarded from the review: Maryudi's (2018) article about wood furniture firms in Indonesia and Deolalikar's (2002) article about the clients of subsidised hospitals in Vietnam. These two articles did not fit into our localnational dichotomy. See the appendix for Scopus' list of the 100 most highly cited articles on 'elite capture'.

2 However, this method fails to include capture even higher up the aid chain, in (government and private) donor institutions.

\section{Bibliography}

Acemoglu, D., \& Robinson, J. (2012). Why Nations Fail The Origins of Power, Prosperity and Poverty by Daron Acemoglu, James A. Robinson (z-lib.org).pdf. London: Profile Books.

Adhikari, K. P., \& Goldey, P. (2010). Social Capital and its "Downside": The Impact on Sustainability of Induced Community-Based Organizations in Nepal. World Development, 38(2), 184-194. https://doi.org/10.1016/j.worlddev.2009.10.012

Agarwal, B. (2001). Participatory Exclusions, Community Forestry, and Gender: An Analysis for South Asia and a Conceptual Framework. World Development, 29(10), 1623-1648. https://doi.org/10.1016/S0305-750X(01)00066-3

Alatas, V., Banerjee, A., Hanna, R., Olken, B. A., Purnamasari, R., \& Wai-Poi, M. (2019). Does Elite Capture Matter? Local Elites and Targeted Welfare Programs in Indonesia. AEA Papers and Proceedings, 109, 334-339. https://doi.org/10.1257/pandp .20191047

Alatas, V., Rema, A. B., Benjamin, H., Tobias, J., \& Olken, A. (2010). Targeting the Poor: Evidence From a Field Experiment in Indonesia. Working Paper $15980 \mathrm{Http} / /$ Www.Nber.Org/Papers/W15980. NATIONAL BUREAU OF ECONOMIC RESEARCH.

Alby, P., \& Auriol, E. (2010). Social Barriers to Entrepreneurship in Africa: The Forced Mutual Help Hypothesis. 36.

Andersson, K. P., Smith, S. M., Alston, L. J., Duchelle, A. E., Mwangi, E., Larson, A. M., de Sassi, C., Sills, E. O., Sunderlin, W. D., \& Wong, G. Y. (2018). Wealth and the Distribution of Benefits from Tropical Forests: Implications for REDD+. Land Use Policy, 72, 510-522. https://doi.org/10.1016/j.landusepol.2018.01.012

Araujo, M. C., Ferreira, F. H. G., Lanjouw, P., \& Özler, B. (2008). Local Inequality and Project Choice: Theory and Evidence from Ecuador. Journal of Public Economics, 92(5-6), 1022-1046. https://doi.org/10.1016/j.jpubeco.2007.12.005

Arcand, J.-L., \& Wagner, N. (2016). Does Community-driven Development Improve Inclusiveness in Peasant Organizations? - Evidence from Senegal. World Development, 78, 105-124. https://doi.org/10.1016/j.worlddev.2015.10.016

Arnall, A., Thomas, D. S. G., Twyman, C., \& Liverman, D. (2013). NGOs, Elite Capture and Community-driven Development: Perspectives in Rural Mozambique. The Journal of Modern African Studies, 51(2), 305-330. https://doi.org/10.1017/S00222 78X13000037 
Aspinall, E. (2014). Health Care and Democratization in Indonesia. Democratization, 21(5), 803-823. https://doi.org/10.1080/13510347.2013.873791

Aune, J. (2011). Agro-Sahel-A Collection of Evidence-Based Techniques and Approaches for Agricultural Improvement in the Sahel. Oslo, Norway: Published by the Drylands Coordination Group (DCG).

Baird, I. G. (2014). The Global Land Grab Meta-Narrative, Asian Money Laundering and Elite Capture: Reconsidering the Cambodian Context. Geopolitics, 19(2), 431453. https://doi.org/10.1080/14650045.2013.811645

Baird, S., McIntosh, C., \& Özler, B. (2013). The Regressive Demands of DemandDriven Development. Journal of Public Economics, 106, 27-41. https://doi.org/10.1016 /j.jpubeco.2013.07.002

Bardhan, P., \& Mookherjee, D. (1999). Relative Capture of Local and National Governments: An Essay in the Political Economy of Decentralization. Working Paper, Institute for Economic Development, Boston University.

Bardhan, P., \& Mookherjee, D. (2000). Capture and Governance at Local and National Levels. American Economic Review, 90(2), 135-139. https://doi.org/10.1257/aer.90.2.135

Bardhan, P., \& Mookherjee, D. (2003). Poverty Alleviation Effort of West Bengal Panchayats. Economic and Political Weekly, 22.

Bardhan, P., \& Mookherjee, D. (2005). Decentralization, Corruption and Government Accountability-An Overview.pdf. In S. Rose-Ackerman (Ed.), Handbook of Economic Corruption. Edward Elgar.

Bardhan, P., \& Mookherjee, D. (2006). Decentralisation and Accountability in Infrastructure Delivery in Developing Countries. The Economic Journal, 116(508), 101-127.

Beath, A., Fotini, C., \& Enikolopov, R. (2011). Elite Capture of Local Institutions: Evidence from a Field Experiment in Afghanistan.

Bergh, S. (2004). Democratic Decentralisation and Local Participation: A Review of Recent Research. Development in Practice, 14(6), 780-790. https://doi.org/10.1080/0 961452042000284012

Bernard, T., Collion, M.-H., de Janvry, A., Rondot, P., \& Sadoulet, E. (2008). Do Village Organizations Make a Difference in African Rural Development? A Study for Senegal and Burkina Faso. World Development, 36(11), 2188-2204. https://doi.org/10 $.1016 /$ j.worlddev.2007.10.010

Berry, S. (1993). No Condition Is Permanent: The Social Dynamics of Agrarian Change in SubSaharan Africa. University of Wisconsin Press.

Binswanger, H. P., \& McIntire, J. (1987). Behavioral and Material Determinants of Production Relations in Land-Abundant Tropical Agriculture. Economic Development and Cultural Change, 36(1), 73-99.

Blair, H. (2000). Participation and Accountability at the Periphery: Democratic Local Governance in Six Countries. World Development, 28(1), 21-39. https://doi.org/10.1 016/S0305-750X(99)00109-6

Bodin, Ö., \& Crona, B. (2011). Barriers and Opportunities in Transforming to Sustainable Governance: The Role of Key Individuals. In O. Bodin \& C. Prell (Eds.), Social Networks and Natural Resource Management (pp. 75-94). Cambridge: Cambridge University Press. https://doi.org/10.1017/CBO9780511894985.005

Boone, C. (1998). State building in the African countryside: Structure and Politics at the Grassroots. Journal of Development Studies, 34(4), 1-31. https://doi.org/10.1080/0 0220389808422527

Boone, C. (2003). Decentralization as Political Strategy in West Africa. Comparative Political Studies, 36(4), 355-380. https://doi.org/10.1177/0010414003251173 
Bornstein, L., Wallace, T., \& Chapman, J. (2006). The Aid Chain: Coercion and Commitment in Development NGOs. Rugby: ITDG Publishing.

Boulding, C. (2009). Accountability in Foreign Aid Delivery: Links between Donors and NGOs. 21.

Bourdieu, P. (1980). The Logic of Practice. Cambridge: Polity Press. Stanford: Stanford University Press.

Bourdieu, P. (1989). La noblesse d'Etat. Grands corps et Grandes ecoles. Paris: Editions de Minuit.

Bourdieu, P., \& Wacquant, L. J. D. (1992). An Invitation to Reflexive Sociology. Cambridge: Polity Press.

Bourdieu, P. (1977). Outline of a Theory of Practice. Cambridge: Cambridge University Press.

Bulte, E., Richards, P., \& Voors, M. (2018). Institutions and Agrarian Development: A New Approach to West Africa. Dordrecht: Springer. https://doi.org/10.1007/978-3-319-9 $8500-8$

Casey, K. (2011). The GoBifo Project Evaluation Report: 56.

Casey, K. (2018). Radical Decentralization: Does Community-driven Development Work? Annual Review of Economics, 10(1), 139-163. https://doi.org/10.1146/annurev -economics-080217-053339

Casey, K., Glennerster, R., \& Miguel, E. (2012). Reshaping Institutions: Evidence on Aid Impacts Using a Preanalysis Plan`. The Quarterly Journal of Economics, 127(4), 1755-1812. https://doi.org/10.1093/qje/qje027

Chambers, R. (2010). Paradigms, Poverty and Adaptive Pluralism. IDS Working Papers, 2010(344), 01-57. https://doi.org/10.1111/j.2040-0209.2010.00344_2.x

Chemouni, B. (2014). Explaining the Design of the Rwandan Decentralization: Elite Vulnerability and the Territorial Repartition of Power. Journal of Eastern African Studies, 8(2), 246-262. https://doi.org/10.1080/17531055.2014.891800

Chomba, S., Kariuki, J., Lund, J. F., \& Sinclair, F. (2016). Roots of Inequity: How the Implementation of REDD+ Reinforces Past Injustices. Land Use Policy, 50, 202-213. https://doi.org/10.1016/j.landusepol.2015.09.021

Chomba, S., Treue, T., \& Sinclair, F. (2015). The Political Economy of Forest Entitlements: Can Community Based Forest Management Reduce Vulnerability at the Forest Margin? Forest Policy and Economics, 58, 37-46. https://doi.org/10.1016/j .forpol.2014.11.011

Chome, N. (2015). 'Devolution is Only for Development'? Decentralization and Elite Vulnerability on the Kenyan Coast. Critical African Studies, 7(3), 299-316. https://doi .org/10.1080/21681392.2015.1075750

Classen, L., Humphries, S., FitzSimons, J., Kaaria, S., Jiménez, J., Sierra, F., \& Gallardo, O. (2008). Opening Participatory Spaces for the Most Marginal: Learning from Collective Action in the Honduran Hillsides. World Development, 36(11), 2402-2420. https://doi.org/10.1016/j.worlddev.2008.04.007

Conning, J., \& Kevane, M. (2002). Community-Based Targeting Mechanisms for Social Safety Nets: A Critical Review. World Development, 30(3), 375-394. https://doi.org /10.1016/S0305-750X(01)00119-X

Cooper, S. J., \& Wheeler, T. (2015). Adaptive Governance: Livelihood Innovation for Climate Resilience in Uganda. Geoforum, 65, 96-107. https://doi.org/10.1016/j.geof orum.2015.07.015

Crespo, J., Réquier-Desjardins, D., \& Vicente, J. (2014). Why Can Collective Action Fail in Local Agri-food Systems? A Social Network Analysis of Cheese Producers in Aculco, Mexico. Food Policy, 46, 165-177. https://doi.org/10.1016/j.foodpol.2014.03 .011 
Cronin, C. (1996). Bourdieu and Foucault on Power and Modernity. Philosophy \& Social Criticism, 22(6), 55-85. https://doi.org/10.1177/019145379602200603

Crook, R. C. (2003). Decentralisation and Poverty Reduction in Africa: The Politics of Local-Central Relations. Public Administration and Development, 23(1), 77-88. https:// doi.org/10.1002/pad.261

Darmawan, R. (2014). Three Essays on Indonesian Political Economy: Elite Capture, Corruption, and Female Policy Makers. Networked Digital Library of Theses \& Dissertations, 2014, 107.

Darmawan, R., \& Klasen, S. (2013). Elite Capture in Urban Development: Evidence from Indonesia. Göttingen: University of Göttingen.

Darrow, M., \& Tomas, A. (2005). Power, Capture, and Conflict: A Call for Human Rights Accountability in Development Cooperation. Human Rights Quarterly, 27(2), 471-538.

Dasgupta, A., \& Beard, V. A. (2007). Community Driven Development, Collective Action and Elite Capture in Indonesia. Development and Change, 38(2), 229-249. https ://doi.org/10.1111/j.1467-7660.2007.00410.x

Daum, T., \& Birner, R. (2017). The Neglected Governance Challenges Of Agricultural Mechanisation in Africa - Insights from Ghana. Food Security, 9(5), 959-979. https:// doi.org/10.1007/s12571-017-0716-9

D'Exelle, B. (2009). Excluded Again: Village Politics at the Aid Interface. Journal of Development Studies, 45(9), 1453-1471. https://doi.org/10.1080/002203809028 90268

Dongier, P., Domelen, J. V., Ostrom, E., Ryan, A., Wakeman, W., Bebbington, A., Alkire, S., Esmail, T., \& Polski, M. (2003). Chapter 9 Community-Driven Development. 1,32 .

Duchoslav, J. (2013). Limiting Elite Capture in Community Driven Development: Evidence from a Randomized Controlled Trial in Sierra Leone. Wageningen: Wageningen University.

Dufhues, T., Theesfeld, I., \& Buchenrieder, G. (2015). The Political Economy of Decentralization in Thailand: How Past and Present Decentralization Affects Rural Actors' Participation. The European Journal of Development Research, 27(5), 793-810. https://doi.org/10.1057/ejdr.2014.68

Dutta, D. (2009). Elite Capture and Corruption: Concepts and Definitions. National Council of Applied Economic Research.

Escobar, A. (1995). El desarrollo sostenible: diálogo de discursos. Ecología política, (9), $7-25$.

Everatt, D., \& Gwagwa, L. (2005). Community Driven Development in South Africa, 19902004. 109.

Findley, M. G., Harris, A. S., Milner, H. V., \& Nielson, D. L. (2017). Who Controls Foreign Aid? Elite versus Public Perceptions of Donor Influence in Aid-dependent Uganda. International Organization, 71(4), 633-663. https://doi.org/10.1017/S00208 18317000273

Finkel, E. (2015). Does Reform Prevent Rebellion? Evidence From Russia's Emancipation of the Serfs. Comparative Political Studies 2015, 48(8), 984-1019.

Fox, J. (2020). Contested Terrain: International Development Projects and Countervailing Power for the Excluded. World Development, 133, 104978. https://doi.org/10.1016/j .worlddev.2020.104978

Fritzen, S. A. (2007). Can the Design of Community-Driven Development Reduce the Risk of Elite Capture? Evidence from Indonesia. World Development, 35(8), 13591375. https://doi.org/10.1016/j.worlddev.2007.05.001 
Galasso, E., \& Ravallion, M. (2005). Decentralized Targeting of an Antipoverty Program. Journal of Public Economics, 89(4), 705-727. https://doi.org/10.1016/j.jpub eco.2003.01.002

García-López, G. A. (2019). Rethinking Elite Persistence in Neoliberalism: Foresters and Techno-Bureaucratic Logics in Mexico's Community Forestry. World Development, 120, 169-181. https://doi.org/10.1016/j.worlddev.2018.03.018

German, L., Schoneveld, G., \& Mwangi, E. (2013). Contemporary Processes of LargeScale Land Acquisition in Sub-Saharan Africa: Legal Deficiency or Elite Capture of the Rule of Law? World Development, 48, 1-18. https://doi.org/10.1016/j.worlddev. 2013.03.006

Ghuman, B. S., \& Singh, R. (2013). Decentralization and Delivery of Public Services in Asia. Policy and Society, 32(1), 7-21. https://doi.org/10.1016/j.polsoc.2013.02.001

Grillos, T. (2017). Participatory Budgeting and the Poor: Tracing Bias in a Multi-Staged Process in Solo, Indonesia. World Development, 96, 343-358. https://doi.org/10.1016 /j.worlddev.2017.03.019

Guijt, I., \& Shah, M. K. (Eds.). (1998). The Myth of Community: Gender issues in participatory development. Rugby: Practical Action Publishing. https://doi.org/10.3362 19781780440309

Gurung, A., Bista, R., Karki, R., Shrestha, S., Uprety, D., \& Oh, S.-E. (2013). Communitybased Forest Management and Its Role in Improving Forest Conditions in Nepal. Small-Scale Forestry, 12(3), 377-388. https://doi.org/10.1007/s11842-012-9217-z

Hall, R., \& Kepe, T. (2017). Elite Capture and State Neglect: New Evidence on South Africa's Land Reform. Review of African Political Economy, 44(151), 122-130. https:// doi.org/10.1080/03056244.2017.1288615

Hardoon, D. (2017). Economy for the 99\%. Oxfam. https://oi-files-d8-prod.s3.eu-west-2 .amazonaws.com/s3fs-public/file_attachments/bp-economy-for-99-percent-160117 -summ-en.pdf

Harsh, M., Mbatia, P., \& Shrum, W. (2010). Accountability and Inaction: NGOs and Resource Lodging in Development. Development and Change, 41(2), 253-278. https:/ /doi.org/10.1111/j.1467-7660.2010.01641.x

He, J. (2016). Rights to Benefit from Forest? A Case Study of the Timber Harvest Quota System in Southwest China. Society \& Natural Resources, 29(4), 448-461. https://doi .org/10.1080/08941920.2015.1062949

Hernández-Trillo, F., \& Jarillo-Rabling, B. (2008). Is Local Beautiful? Fiscal Decentralization in Mexico. World Development, 36(9), 1547-1558. https://doi.org/10 .1016/j.worlddev.2007.09.008

Herrmann, R. T. (2017). Large-Scale Agricultural Investments and Smallholder Welfare: A Comparison of Wage Labor and Outgrower Channels in Tanzania. World Development, 90, 294-310. https://doi.org/10.1016/j.worlddev.2016.10.007

Higgins, D., Balint, T., Liversage, H., \& Winters, P. (2018). Investigating the Impacts of Increased Rural Land Tenure Security: A Systematic Review of the Evidence. Journal of Rural Studies, 61, 34-62. https://doi.org/10.1016/j.jrurstud.2018.05.001

Hillebrand, E. (2009). Poverty, Growth, and Inequality Over The Next 50 Years. In Piero Conforti, ed., Looking Ahead in World Agriculture: Perspectives to 2050. Rome: Food and Agriculture Organization of the United Nations, 159-190.

Hinnerich, B., \& Pettersson-Lidbom, P. (2014). Democracy, Redistribution, and Political Participation: Evidence From Sweden 1919-1938. Econometrica, 82(3), 961-993. https://doi.org/10.3982/ECTA9607

Holdcroft, L. (1978). The Rise and Fall of Community Development in Developing Countries, 1950-65. Michigan State University. Rural Development. Paper No.2, 79. 
Holden, S. T., \& Otsuka, K. (2014). The Roles of Land Tenure Reforms and Land Markets in the Context of Population Growth and Land Use Intensification in Africa. Food Policy, 48, 88-97. https://doi.org/10.1016/j.foodpol.2014.03.005

Humphreys, M. (2012). Social and Economic Impacts of Tuungane: Final Report on the Effects of a Community Driven Reconstruction Programme in the Democratic Republic of Congo. 3ie Impact Evaluation Report 7. New Delhi: International Initiative for Impact Evaluation (3ie).

Hussein, K., \& Nelson, J. (1998). Sustainable Livelihoods and Livelihood Diversification. IDS WORKING PAPER 69, 32.

IRC \& CARE. (2012). Annual Review of Tuungane.doc. ARIES CODE: 105862. http:// iati.dfid.gov.uk/iati_documents/4131936.odt.

Iversen, V., Chhetry, B., Francis, P., Gurung, M., Kafle, G., Pain, A., \& Seeley, J. (2006). High Value Forests, Hidden Economies and Elite Capture: Evidence from Forest User Groups in Nepal's Terai. Ecological Economics, 58(1), 93-107. https://doi.org/10.1016 /j.ecolecon.2005.05.021

Jackson, P. (2011). Decentralised Power and Traditional Authorities: How Power Determines Access to Justice in Sierra Leone. The Journal of Legal Pluralism and Unofficial Law, 43(63), 207-230. https://doi.org/10.1080/07329113.2011.10756662

Kamoto, J., Clarkson, G., Dorward, P., \& Shepherd, D. (2013). Doing More Harm Than Good? Community Based Natural Resource Management and the Neglect of Local Institutions in Policy Development. Land Use Policy, 35, 293-301. https://doi.org/10 .1016/j.landusepol.2013.06.002

Kazianga, H. (2006). Motives for Household Private Transfers in Burkina Faso. Journal of Development Economics, 79(1), 73-117. https://doi.org/10.1016/j.jdeveco.2005.06.001

Khadka, M. (2009). Why Does Exclusion Continue?: Aid, Knowledge and Power in Nepal's Community Forestry Policy Process. Düren: Shaker Pub.

Khatun, K., Gross-Camp, N., Corbera, E., Martin, A., Ball, S., \& Massao, G. (2015). When Participatory Forest Management Makes Money: Insights from Tanzania on Governance, Benefit Sharing, and Implications for REDD+. Environment and Planning A: Economy and Space, 47(10), 2097-2112. https://doi.org/10.1177/0308518X15595899

Kita, S. M. (2019). Barriers or Enablers? Chiefs, Elite Capture, Disasters, and Resettlement In Rural Malawi. Disasters, 43(1), 135-156. https://doi.org/10.1111/disa.12295

Kothari, U. (2001). Power, Knowledge and Social Control in Participatory Development. Published in Participation: The New Tyranny? London: Zed Books.

Kumar, N., Vajja, A., Pozzoni, B., \& Woodall, G. G. (2005). The Effectiveness of World Bank Support for Community-Based and-Driven Development: An OED Evaluation. The World Bank. https://doi.org/10.1596/978-0-8213-6390-4

Kundu, D. (2011). Elite Capture in Participatory Urban Governance. 10, 3.

Kusumawati, R., \& Visser, L. (2016). Capturing the Elite in Marine Conservation in Northeast Kalimantan. Human Ecology, 44(3), 301-310. https://doi.org/10.1007/s 10745-016-9830-0

Labonte, M. T. (2012). From Patronage to Peacebuilding? Elite Capture and Governance from below in Sierra Leone. African Affairs, 111(442), 90-115. https://doi.org/10.1093 /afraf/adr073

Lake, M. (2017). Building the Rule of War: Postconflict Institutions and the MicroDynamics of Conflict in Eastern DR Congo. International Organization, 71(2), 281315. https://doi.org/10.1017/S002081831700008X

Lange, S., \& Kinyondo, A. (2016). Resource Nationalism and Local Content in Tanzania: Experiences from Mining and Consequences for the Petroleum Sector. The Extractive Industries and Society, 3(4), 1095-1104. https://doi.org/10.1016/j.exis.2016.09.006 
Lawson, B. S. (2011). Developing Stability: Community-Driven Development and Reconstruction in Conflict-Affected Settings. 306.

le Meur, P.-Y. (1999). Décentralisation par le bas et participation clientéliste au Benin. Published in Les Dimensions Sociales Et Economiques Du Developpement Local Et La Decentralisation En Afrique Au Sud Du Sahara. Lit Verlag; Bilingual edition. https://journals.openedit ion.org/apad $/ 562$

Lebert, T., \& Rohde, R. (2007). Land Reform and the New Elite: Exclusion of the Poor from Communal Land in Namaqualand, South Africa. Journal of Arid Environments, 70(4), 818-833. https://doi.org/10.1016/j.jaridenv.2006.03.023

Lee, Y. S. (2018). International Isolation and Regional Inequality: Evidence from Sanctions on North Korea. Journal of Urban Economics, 103, 34-51. https://doi.org/10 $.1016 /$ j.jue.2017.11.002

Lewis, B. D. (2005). Indonesian Local Government Spending, Taxing and Saving: An Explanation of Pre- and Post-decentralization Fiscal Outcomes ${ }^{\star}$. Asian Economic Journal, 19(3), 291-317. https://doi.org/10.1111/j.1467-8381.2005.00214.x

Li, T. M. (2007). The Will to Improve. Durham \& London: Duke University Press.

Liu, Z., Müller, M., Rommel, J., \& Feng, S. (2016). Community-based Agricultural Land Consolidation and Local Elites: Survey Evidence from China. Journal of Rural Studies, 47, 449-458. https://doi.org/10.1016/j.jrurstud.2016.06.021

Long, N. (2003). Development Sociology: Actor Perspectives. London: Routledge. https://doi .org/10.4324/9780203398531

Lucas, A. (2016). Elite Capture and Corruption in Two Villages in Bengkulu Province, Sumatra. Human Ecology, 44(3), 287-300. https://doi.org/10.1007/s10745-016-9837-6

Lund, C., \& Benjaminsen, T. A. (2001). Politics, Property, and Production in the West African Sahel: Understanding Natural Resources Management. Uppsala: Nordiska Afrikainstitutet.

Lund, J. F. (2015). Paradoxes of Participation: The Logic of Professionalization in Participatory Forestry. Forest Policy and Economics, 60, 1-6. https://doi.org/10.1016/j .forpol.2015.07.009

Lund, J. F., \& Saito-Jensen, M. (2013). Revisiting the Issue of Elite Capture of Participatory Initiatives. World Development, 46, 104-112. https://doi.org/10.1016/j .worlddev.2013.01.028

MacArthur, J., \& Matthewman, S. (2018). Populist Resistance and Alternative Transitions: Indigenous Ownership of Energy Infrastructure in Aotearoa New Zealand. Energy Research E Social Science, 43, 16-24. https://doi.org/10.1016/j.erss.2018.05.009

Manor, J. (1999). The Political Economy of Democratic Decentralization. The World Bank. https://doi.org/10.1596/0-8213-4470-6

Mansuri, G., \& Rao, V. (2003). Evaluating Community-Based and Community-Driven Development: A Critical Review of the Evidence. 54.

Mapedza, E., \& Bond, I. (2006). Political Deadlock and Devolved Wildlife Management in Zimbabwe: The Case of Nenyunga Ward. The Journal of Environment \& Development, 15(4), 407-427. https://doi.org/10.1177/1070496506294635

Martinez-Bravo, M., Mukherjee, P., \& Stegmann, A. (2017). The Non-democratic Roots of Elite Capture: Evidence From Soeharto Mayors in Indonesia. Econometrica, 85(6), 1991-2010. https://doi.org/10.3982/ECTA14125

Mattingly, D. C. (2016). Elite Capture: How Decentralization and Informal Institutions Weaken Property Rights in China. World Politics, 68(3), 383-412. https://doi.org/10 .1017/S0043887116000083

Mawomo, K. (2019). The Dynamics of Community Participation: Evidence from Practice. Keele University, England. 
McMillan, R., Spronk, S., \& Caswell, C. (2014). Popular Participation, Equity, and Co-Production of Water and Sanitation Services in Caracas, Venezuela. Water International, 39(2), 201-215. https://doi.org/10.1080/02508060.2014.886844

Miller, J. (1988). The ghostly body politic: The federalist papers and popular sovereignty. Political Theory. 16, 99-119.

Minamoto, Y. (2010). Social Capital and Livelihood Recovery: Post-tsunami Sri Lanka as a Case. Disaster Prevention and Management: An International Journal, 19(5), 548-564. https://doi.org/10.1108/09653561011091887

Mitra, S. K. (1991). Room to Maneuver in the Middle: Local Elites, Political Action, and the State in India. World Politics, 43(3), 390-413. https://doi.org/10.2307/2010400

Mohammed, A. J., \& Inoue, M. (2014). Linking Outputs and Outcomes from Devolved Forest Governance Using a Modified Actor-Power-Accountability Framework (MAPAF): Case Study from Chilimo Forest, Ethiopia. Forest Policy and Economics, 39, 21-31. https://doi.org/10.1016/j.forpol.2013.11.005

Morck, R., Deniz Yavuz, M., \& Yeung, B. (2011). Banking System Control, Capital Allocation, and Economy Performance 3 . Journal of Financial Economics, 100(2), 264283. https://doi.org/10.1016/j.jfineco.2010.12.004

Musgrave, M. K., \& Wong, S. (2016). Towards a More Nuanced Theory of Elite Capture in Development Projects. The Importance of Context and Theories of Power. Journal of Sustainable Development, 9(3), 87. https://doi.org/10.5539/jsd.v9n3p87

Mustafa, D., Altz-Stamm, A., \& Scott, L. M. (2016). Water User Associations and the Politics of Water in Jordan. World Development, 79, 164-176. https://doi.org/10.1016 /j.worlddev.2015.11.008

Mwangi, E., \& Dohrn, S. (2008). Securing Access to Drylands Resources for Multiple Users in Africa: A Review of Recent Research. Land Use Policy, 25(2), 240-248. https ://doi.org/10.1016/j.landusepol.2007.07.002

Nadiruzzaman, M., \& Wrathall, D. (2014). Participatory Exclusion-Elite capture of participatory approaches in the aftermath of Cyclone Sidr. UNU-EHS Working Paper Series No. 3. https://doi.org/10.13140/2.1.2185.5529

Nath, A. (2014). Political Competition and Elite Capture of Local Public Goods. Working Paper, 38.

Oberlack, C., Tejada, L., Messerli, P., Rist, S., \& Giger, M. (2016). Sustainable Livelihoods in the Global Land Rush? Archetypes of Livelihood Vulnerability and Sustainability Potentials. Global Environmental Change, 41, 153-171. https://doi.org/10.1016/j.gloe nvcha.2016.10.001

Olken, B. (2005). Monitoring Corruption: Evidence from a Field Experiment in Indonesia. NBER Working Paper No. 11753 November 2005.

Olowu, D. (2003). Local Institutional and Political Structures and Processes: Recent Experience in Africa. Public Administration and Development, 23(1), 41-52. https://doi .org/10.1002/pad.258

Pacheco, P., de Jong, W., \& Johnson, J. (2010). The Evolution of the Timber Sector in Lowland Bolivia: Examining the Influence of Three Disparate Policy Approaches. Forest Policy and Economics, 12(4), 271-276. https://doi.org/10.1016/j.forpol.2009.12 .002

Pan, L., \& Christiaensen, L. (2012). Who is Vouching for the Input Voucher? Decentralized Targeting and Elite Capture in Tanzania. World Development, 40(8), 1619-1633. https://doi.org/10.1016/j.worlddev.2012.04.012

Panda, S. (2015). Political Connections and Elite Capture in a Poverty Alleviation Programme in India. The Journal of Development Studies, 51(1), 50-65. https://doi.org $/ 10.1080 / 00220388.2014 .947281$ 
Persha, L., \& Andersson, K. (2014). Elite Capture Risk and Mitigation in Decentralized Forest Governance Regimes. Global Environmental Change, 24, 265-276. https://doi .org/10.1016/j.gloenvcha.2013.12.005

Pfeiffer, J. (2003). International NGOs and Primary Health Care in Mozambique: The Need for a New Model of Collaboration. Social Science \& Medicine, 56(4), 725-738. https://doi.org/10.1016/S0277-9536(02)00068-0

Phillips, D., Waddington, H., \& White, H. (2014). Better Targeting of Farmers as a Channel For Poverty Reduction: A Systematic Review of Farmer Field Schools targeting. Development Studies Research, 1(1), 113-136. https://doi.org/10.1080/2 1665095.2014.924841

Pitcher, A., Moran, M. H., \& Johnston, M. (2009). Rethinking Patrimonialism and Neopatrimonialism in Africa. African Studies Review, 52(1), 125-156. https://doi.org /10.1353/arw.0.0163

Platteau, J.-P. (2004). Monitoring Elite Capture in Community-driven Development. Development and Change, 35(2), 223-246. https://doi.org/10.1111/j.1467-7660.2004 $.00350 . \mathrm{x}$

Platteau, J.-P. (2006). Chapter 12 Solidarity Norms and Institutions in Village Societies: Static and Dynamic Considerations. In Handbook of the Economics of Giving, Altruism and Reciprocity (Vol. 1, pp. 819-886). Elsevier. https://doi.org/10.1016/S1574-0714( 06)01012-8

Platteau, J.-P. (2009). Information Distortion, Elite Capture, and Task Complexity in Decentralised Development. Working Papers 1104, University of Namur, Department of Economics, 54.

Platteau, J.-P., \& Gaspart, F. (2003). The Risk of Resource Misappropriation in Community-Driven Development. World Development, 31(10), 1687-1703. https://do i.org/10.1016/S0305-750X(03)00138-4

Platteau, J.-P., Somville, V., \& Wahhaj, Z. (2014). Elite Capture through Information Distortion: A Theoretical Essay. Journal of Development Economics, 106, 250-263. https ://doi.org/10.1016/j.jdeveco.2013.10.002

Platteau, J.-P., \& Abraham, A. (2002). Participatory Development in the Presence of Endogenous Community Imperfections. Journal of Development Studies, 39(2), 104136. https://doi.org/10.1080/00220380412331322771

Power, G., Maury, M., \& Maury, S. (2002). Operationalising Bottom-Up Learning in International NGOs: Barriers and Alternatives. Development in Practice, 12(3/4), 272-284.

Powis, B. (2007). Systems of Capture: Reassessing the Threat of Local Elites. World Bank. Social Development Papers, South Asia Series, Paper No.109.

Price, J. I., Janmaat, J., Sugden, F., \& Bharati, L. (2016). Water Storage Systems and Preference Heterogeneity in Water-Scarce Environments: A Choice Experiment in Nepal's Koshi River Basin. Water Resources and Economics, 13, 6-18. https://doi.org/10 $.1016 /$ j.wre.2015.09.003

Prinsen, G., \& Titeca, K. (2008). Uganda's Decentralised Primary Education: Musical Chairs and Inverted Elite Capture in School Management Committees. Public Administration and Development, 28(2), 149-164. https://doi.org/10.1002/pad.487

Prokopy, L. S. (2009). Determinants and Benefits of Household Level Participation in Rural Drinking Water Projects in India. The Journal of Development Studies, 45(4), 471-495. https://doi.org/10.1080/00220380802265504

Putzel, L., Kelly, A. B., Cerutti, P. O., \& Artati, Y. (2015). Formalization as Development in Land and Natural Resource Policy. Society \& Natural Resources, 28(5), 453-472. https://doi.org/10.1080/08941920.2015.1014608 
Rao, V., \& Ibáñez, A. M. (2005). The Social Impact of Social Funds in Jamaica: A 'Participatory Econometric' Analysis of Targeting, Collective Action, and Participation in Community-Driven Development. Journal of Development Studies, 41(5), 788-838. https://doi.org/10.1080/00220380500145297

Ribot, J. C. (2004). Waiting for Democracy: The Politics of Choice in Natural Resource Decentralization. Washington: World Resources Institute.

Rigon, A. (2014). Building Local Governance: Participation and Elite Capture in Slumupgrading in Kenya: Participation and Elite Capture in Kenya. Development and Change, 45(2), 257-283. https://doi.org/10.1111/dech.12078

Rusca, M., Schwartz, K., Hadzovic, L., \& Ahlers, R. (2015). Adapting Generic Models through Bricolage: Elite Capture of Water Users Associations in Peri-urban Lilongwe. The European Journal of Development Research, 27(5), 777-792. https://doi.org/10.1057 /ejdr.2014.58

Russell, A. J. M., \& Dobson, T. (2011). Chiefs as Critical Partners for Decentralized Governance of Fisheries: An Analysis of Co-Management Case Studies in Malawi. Society \& Natural Resources, 24(7), 734-750. https://doi.org/10.1080/08941920.2010 .501432

Saguin, K. (2018). Why the Poor Do Not Benefit from Community-driven Development: Lessons from Participatory Budgeting. World Development, 112, 220-232. https://doi .org/10.1016/j.worlddev.2018.08.009

Saito-Jensen, M., Nathan, I., \& Treue, T. (2010). Beyond Elite Capture? Communitybased Natural Resource Management and Power in Mohammed Nagar Village, Andhra Pradesh, India. Environmental Conservation, 37(3), 327-335. https://doi.org /10.1017/S0376892910000664

Saul, M. (1983). Work Parties, Wages, and Accumulation in a Voltaic Village. American Ethnologist, 10(1), 77-96. https://doi.org/10.1525/ae.1983.10.1.02a00050

Scott, J. (1985). Weapons of the Weak: Everyday Forms of Peasant Resistance. New Haven: Yale University Press.

Sheely, R. (2015). Mobilization, Participatory Planning Institutions, and Elite Capture: Evidence from a Field Experiment in Rural Kenya. World Development, 67, 251-266. https://doi.org/10.1016/j.worlddev.2014.10.024

Sitko, N. J., Chamberlin, J., \& Hichaambwa, M. (2014). Does Smallholder Land Titling Facilitate Agricultural Growth?: An Analysis of the Determinants and Effects of Smallholder Land Titling in Zambia. World Development, 64, 791-802. https://doi .org/10.1016/j.worlddev.2014.07.014

Sitko, N. J., \& Jayne, T. S. (2014). Structural Transformation or Elite Land Capture? The Growth of "emergent" Farmers in Zambia. Food Policy, 48, 194-202. https://doi.org /10.1016/j.foodpol.2014.05.006

Smoke, P. (2003). Decentralisation in Africa: Goals, Dimensions, Myths and Challenges. Public Administration and Development, 23(1), 7-16. https://doi.org/10.1002/pad.255

Sovacool, B. K. (2018). Bamboo Beating Bandits: Conflict, Inequality, and Vulnerability in the Political Ecology of Climate Change Adaptation in Bangladesh. World Development, 102, 183-194. https://doi.org/10.1016/j.worlddev.2017.10.014

Spurr, D. (1993). Colonial Discourse in Journalism, Trav l Writing, and Imperial Administration. Durham: Duke University Press.

Tai, H.-S. (2007). Development Through Conservation: An Institutional Analysis of Indigenous Community-Based Conservation in Taiwan. World Development, 35(7), 1186-1203. https://doi.org/10.1016/j.worlddev.2006.09.015

Takasaki, Y. (2011a). Targeting Cyclone Relief within the Village: Kinship, Sharing, and Capture. Economic Development and Cultural Change, 59(2) (January 2011), 387-416. 
Takasaki, Y. (2011b). Do Local Elites Capture Natural Disaster Reconstruction Funds? Journal of Development Studies, 47(9), 1281-1298. https://doi.org/10.1080/00220388 .2010 .509786

Thomas, G. M., Chhetri, N., \& Hussaini, K. (2008). Legitimacy and the Rise of NGOs: The Global and Local in South Asia. Journal of Civil Society, 4(1), 31-42. https://doi .org/10.1080/17448680802051139

Thompson, B. S. (2017). Can Financial Technology Innovate Benefit Distribution in Payments for Ecosystem Services and REDD+? Ecological Economics, 139, 150-157. https://doi.org/10.1016/j.ecolecon.2017.04.008

To, P. X., Dressler, W. H., Mahanty, S., Pham, T. T., \& Zingerli, C. (2012). The Prospects for Payment for Ecosystem Services (PES) in Vietnam: A Look at Three Payment Schemes. Human Ecology, 40(2), 237-249. https://doi.org/10.1007/s10745 -012-9480-9

Townsend, J. G., Porter, G., \& Mawdsley, E. (2002). The Role of the Transnational Community of Non-government Organizations: Governance or Poverty Reduction? Journal of International Development, 14(6), 829-839. https://doi.org/10 $.1002 /$ jid. 928

Tschakert, P. (2016). Shifting Discourses of Vilification and the Taming of Unruly Mining Landscapes in Ghana. World Development, 86, 123-132. https://doi.org/10.1 016/j.worlddev.2016.05.008

UNDP. (2010). The Real Wealth of Nations: Pathways to Human Development. Human Development Report 2010 20th Anniversary Edition, 238.

Vajja, A., \& White, H. (2008). Can the World Bank Build Social Capital? The Experience of Social Funds in Malawi and Zambia. The Journal of Development Studies, 44(8), 1145-1168. https://doi.org/10.1080/00220380802242404

van Geen, A., Ahmed, K. M., Ahmed, E. B., Choudhury, I., Mozumder, M. R., Bostick, B. C., \& Mailloux, B. J. (2016). Inequitable Allocation of Deep Community Wells for Reducing Arsenic Exposure in Bangladesh. Journal of Water, Sanitation and Hygiene for Development, 6(1), 142-150. https://doi.org/10.2166/washdev.2015.115

Verbrugge, B. (2015). Decentralization, Institutional Ambiguity, and Mineral Resource Conflict in Mindanao, Philippines. World Development, 67, 449-460. https://doi.org /10.1016/j.worlddev.2014.11.007

Verma, R. (2014). Land Grabs, Power, and Gender in East and Southern Africa: So, What's New? Feminist Economics, 20(1), 52-75. https://doi.org/10.1080/13545701.20 14.897739

Vicol, M., Neilson, J., Hartatri, D. F. S., \& Cooper, P. (2018). Upgrading for Whom? Relationship Coffee, Value Chain Interventions and Rural Development in Indonesia. World Development, 110, 26-37. https://doi.org/10.1016/j.worlddev.2018.05.020

Walsh, E., \& Lenihan, H. (2006). Accountability and Effectiveness of NGOs: Adapting Business Tools Successfully. Development in Practice, 16(5), 412-424.

Ward, C., Holmes, G., \& Stringer, L. (2018). Perceived Barriers to and Drivers of Community Participation in Protected-area Governance: Protected-Area Governance. Conservation Biology, 32(2), 437-446. https://doi.org/10.1111/cobi .13000

Warren, C., \& Visser, L. (2016). The Local Turn: An Introductory Essay Revisiting Leadership, Elite Capture and Good Governance in Indonesian Conservation and Development Programs. Human Ecology, 44(3), 277-286. https://doi.org/10.1007/s 10745-016-9831-z

Wenar, L. (2006). Accountability in International Development Aid. Ethics \& International Affairs, 20(1), 1-23. https://doi.org/10.1111/j.1747-7093.2006.00001.x 
Williams, G., Veron, R., Corbridge, S., \& Srivastava, M. (2003). Participation and Power: Poor People's Engagement with India's Employment Assurance Scheme. Development and Change, 34(1), 163-192. https://doi.org/10.1111/1467-7660.00300

Wilmsen, B. (2016). Expanding capitalism in Rural China Through Land Acquisition and Land Reforms. Journal of Contemporary China, 25(101), 701-717. https://doi.org $/ 10.1080 / 10670564.2016 .1160504$

Wong, S. (2010). Elite Capture or Capture Elites? Lessons from the 'Counter-elite' and 'Co-optelite' Approaches in Bangladesh and Ghana. 21.

Wong, Sam. (2013). Challenges to the Elite Exclusion-Inclusion DichotomyReconsidering Elite Capture in Community-based Natural Resource Management. South African Journal of International Affairs, 20(3), 379-391. https://doi.org/10.1080/1 0220461.2013 .841800

Wong, S. (2012). What Have Been the Impacts of World Bank Community-Driven Development Programs? The World Bank Social Development Department Sustainable Development Network.

Yilmaz, S., \& Venugopal, V. (2013). Local Government Discretion and Accountability in Philippines. Journal of International Development, 25(2), 227-250. https://doi.org/10 $.1002 /$ jid. 1687

Zulu, L. (2013). Bringing People Back into Protected Forests in Developing Countries: Insights from Co-Management in Malawi. Sustainability, 5(5), 1917-1943. https://doi .org/10.3390/su5051917

\section{Appendix}

(Adhikari \& Goldey, 2010; Alatas et al., 2010; Andersson et al., 2018; Araujo et al., 2008; Arnall et al., 2013; Aspinall, 2014; I. G. Baird, 2014; S. Baird et al., 2013; Bernard et al., 2008; Bodin \& Crona, 2011; Chemouni, 2014; Chomba et al., 2015, 2016; Chome, 2015; Classen et al., 2008; Cooper \& Wheeler, 2015; Crespo et al., 2014; Crook, 2003; Darrow \& Tomas, 2005; Dasgupta \& Beard, 2007; Daum \& Birner, 2017; Findley et al., 2017; Finkel, 2015; Fritzen, 2007; García-López, 2019; German et al., 2013; Ghuman \& Singh, 2013; Grillos, 2017; Gurung et al., 2013; Hall \& Kepe, 2017; He, 2016; Hernández-Trillo \& Jarillo-Rabling, 2008; Herrmann, 2017; Higgins et al., 2018; Hinnerich \& Pettersson-Lidbom, 2014; Holden \& Otsuka, 2014; Iversen et al., 2006; Jackson, 2011; Kamoto et al., 2013; Khatun et al., 2015; Kundu, 2011; Labonte, 2012; Lake, 2017; Lange \& Kinyondo, 2016; Lebert \& Rohde, 2007; Lee, 2018; Lewis, 2005; Liu et al., 2016; J. F. Lund, 2015; J. F. Lund \& Saito-Jensen, 2013; MacArthur \& Matthewman, 2018; Mapedza \& Bond, 2006; Martinez-Bravo et al., 2017; Mattingly, 2016; McMillan et al., 2014; Minamoto, 2010; Mohammed \& Inoue, 2014; Morck et al., 2011; Mustafa et al., 2016; Mwangi \& Dohrn, 2008; Nadiruzzaman \& Wrathall, 2014; Oberlack et al., 2016; Olken, 2005; Olowu, 2003; Pacheco et al., 2010; Pan \& Christiaensen, 2012; Panda, 2015; Persha \& Andersson, 2014; Phillips et al., 2014; Jean-Philippe Platteau, 2004; Jean-Philippe Platteau et al., 2014; Jean-Philippe Platteau \& Gaspart, 2003; Price et al., 2016; Prinsen \& Titeca, 2008; Prokopy, 2009; Putzel et al., 2015; Rigon, 2014; Rusca et al., 2015; Russell \& Dobson, 2011; Saito-Jensen et al., 2010; 
Sheely, 2015; Sitko et al., 2014; Sitko \& Jayne, 2014; Sovacool, 2018; Tai, 2007; Takasaki, 2011a, 2011b; Thompson, 2017; To et al., 2012; Tschakert, 2016; Vajja \& White, 2008; van Geen et al., 2016; Verbrugge, 2015; Verma, 2014; Vicol et al., 2018; Ward et al., 2018; Warren \& Visser, 2016; Wilmsen, 2016; Yilmaz \& Venugopal, 2013; Zulu, 2013). 